\title{
THE ARTISTIC AND MATERIAL DIMENSION OF UFO CULTURE
}

ISTVÁN POVEDÁK

This article aims to introduce the artistic and material dimensions of UFO culture. Various artifacts will be examined from a functionalist and phenomenologist perspective within historical contexts.

Keywords: UFO religions, mythology, UFO art, material religion
Članek predstavlja umetniške in materialne razsežnosti kulture NLP (neznani leteči predmeti). Različni artefakti so v zgodovinskih kontekstih preučeni s funkcionalističnega in fenomenološkega vidika.

Ključne besede: religije NLP, mitologija, umetnost NLP, materialna religija

In 2016, an exhibition of Stephen Warde Anderson opened at The Rockford Art Museum (RAM) in Illinois entitled "The Wonderful World of Stephen Warde Anderson". At first glance, there seemed to be nothing special in this news, although Anderson's name most likely is unknown to most readers. Nevertheless, in addition to RAM, Anderson's paintings can be found at the Smithsonian American Art Museum, the American Folk Art Museum, the Roger Brown Study Collection of the Art Institute of Chicago, the Milwaukee Art Museum, and the Freeport Art Museum.

Although largely unknown by the general public, Anderson has gained a reputation in the museum world, and thus there would seem to be nothing strange in an additional exhibition of his work. What does make the news seem peculiar, however, is the theme of his art work. In Anderson's naïve paintings, reptilians attack peaceful American passers-by, gray aliens date in a park or just sit on a bench having breakfast and listening to music, dressed in human attire. Hearing about the exhibition, skeptics may accuse Anderson of sensationalism, of being a semi-talented painter riding the wave of popular UFO enthusiasm and depicting an eye-catching phenomenon in the hope of success. Such criticism may be accurate, but we folklorists are not in the position to make such judgments. However, it is worth noting that painting "sensationalist" topics alone will not necessarily result in success. Success also requires a larger-sized host community, a group of fans (or believers) who like or even adore those artifacts or their creator. No matter how sensational a topic might be, if it does not appeal to the preferences of the community, it will be immersed in oblivion.

This article aims to make an excursion to discover the artistic and material dimensions of UFO culture, a rarely explored area. The artifacts will be examined from a functionalist and phenomenologist perspective within historical contexts without aiming to apply aesthetic preferences and judge their artistic or non-artistic level. As a pioneer recapitulative article in a mainly unexplored field, its ultimate goal is to shed more light on a gray spot in UFO culture and stimulate further research. 


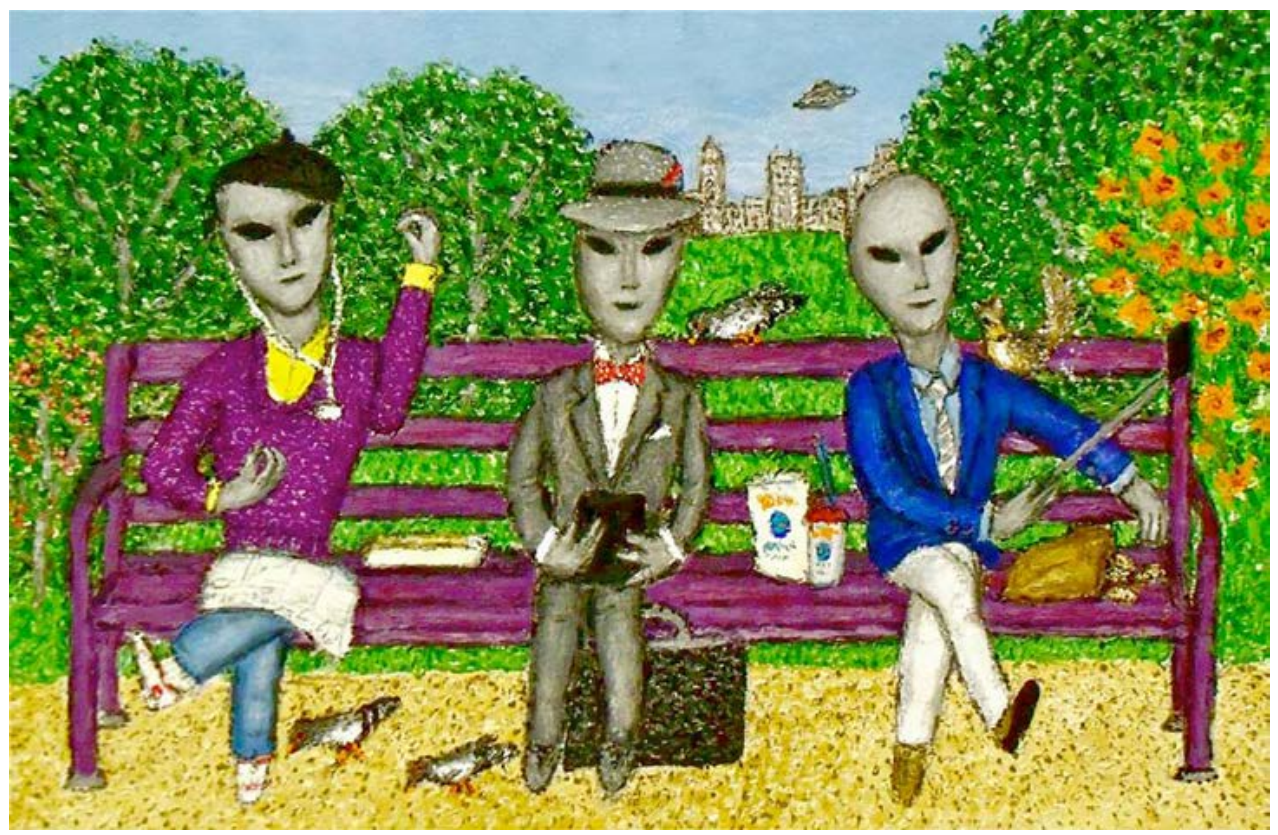

Figure 1. Stephen Warde Anderson: Clueless Gray Aliens on a Park Bench, 2015 (https://toryfolliard. com/news-blog/2016/2/9/the-wonderful-world-of-stephen-warde-anderson-rockford-art-museum-2016).

\section{UFO CULTURE OR UFO CULTURES?}

The Achilles heel of the overview of writings on UFO culture is the incomprehensible measure of sources. It would require a book of series to provide a satisfactory summary of a global phenomenon with decades or even centuries of history. Multiple modernities have produced various UFO cultures that have had different characteristics, meanings, functions, and evaluations in each historical era and region. While the UFO culture of the so-called "Western Hemisphere" is relatively well explored (e.g., Partridge, 2003; Lewis, 2003; Bullard, 2010; Colavito, 2011), it is almost utterly undiscovered in other parts of the world from the socio-scientific perspective. For instance, hardly any information exists concerning the phenomenon in the post-Socialist states ((Köiva, 1996; Ramet, 2003; Povedák, 2018, 2019). ${ }^{1}$ This contributes to the assumption that post-Socialist UFO culture at first glance might seem to be a borrowed version of its Western-primarily American-counterpart, which was developed and adapted to local conditions belatedly as a result of globalization (Ramet, 2003: 212-213). Contrary to the "western world" where UFO culture was an integral part of popular culture with UFO magazines, parades, festivals, and even UFO

1 Research about UFO culture in developing nations (a.k.a. "Third World Countries") is even more scarce. 
religions (Partridge, 2003), the UFO culture in the former Soviet bloc is characterized by a semi-underground political character (Povedák, 2019). UFO subculture there mainly existed hidden from the eyes of the state authorities. The existence of extraterrestrial civilizations and their possible visitations on Earth were rarely the subject of any public discourse. A limited amount of information may be obtained mainly from secret police files monitoring the activities of spiritualist and Theosophist underground groups as no magazines or radio and T.V. shows were made about UFO culture in the era. There were a few journal articles and book chapters published on the topic but always with an "enlightening" intention to refute the existence of extraterrestrials and focusing on the "western" side of the Iron Curtain as if the phenomena did not exist in the communist states (Povedák, 2019). ${ }^{2}$ Thus, there was little opportunity via official channels at that time to import the flourishing UFO culture from the other side of the Iron Curtain. Local variants of "western" UFO narratives on UFO abductions and alien encounters eventually appeared in the 1980s due to the easing of cultural policy (Cielebiaś, 2015; Farcas, 2016). Autochthon UFO mythologies-usually emphasizing the connection between the extraterrestrial species and the given ethnic community - appeared even later, around the turn of the millennium, but not everywhere in the region (Povedák, 2018).

The situation is further complicated by the fact that it is impossible to speak uniformly of "UFO believers" as there are significant differences, even contradictions in what they believe, how they believe, and what role that plays in their vernacular culture. Belief in the existence of extraterrestrial species might be only one otherwise insignificant segment of worldview for many, while such a belief might function as the core element in a religion for others. As Partridge notes, some individuals regularly participate in various rites and UFO festivals or even become members of E.T. religions (Partridge, 2003). Again, others mix and match UFO faith with elements of other religion(s), resulting in a bricolage vernacular religion (Primiano, 1995) where extraterrestrial aliens fit well with saints and prophets. ${ }^{3} \mathrm{It}$ is therefore impossible to speak of a global UFO culture. Researchers consistently have to reflect on its diversity in time and space, which also is true for considering the artistic and material dimensions of UFO culture.

\section{THE MATERIAL DIMENSION OF UFO CULTURE}

Religious studies scholars, among others, interpret the doctrines, structure, or the interconnections of UFO religions with other spiritual and esoteric movements (Partridge, 2003). Folklorists often reach back in time and examine whether UFO beliefs can be derived as

2 This attitude could be observed concerning other new religious movements and religious renewal movements during Communism. See Povedák K., 2011, 2013, 2014; Kapaló, Povedák 2021.

3 See for instance Figure 5 in this paper. 
contemporary "revivals" of prior beliefs or analyze the current variations of UFO narratives and mythologies. (Bullard, 2010; Colavito, 2011; Povedák, 2018). Media researchers compare the alien mythology of newspapers, magazines, and movies, their development, and social reception dating to the 19th century (Jacobs, 1975). At the same time, psychologists have examined, among others, the social symptoms behind the phenomenon (Jung, 1959), the underlying motivations of believers, or the conspiracy-like aspects (Barkun, 2003), or even the mental features of those who report their experience of abduction (Jacobs, 1992). Albeit only a tiny minority of researchers are aware that the artistic/material dimension of UFO culture exists and includes all the perceptible - a.k.a. visible, tangible, audible - artifacts and objects, through which UFO faith is manifested (Meder, 2007; Wojcik, 2016: 216-225, 2022). These are all integral parts for understanding the phenomenon; still, the focus of scholars has been almost exclusively directed by mythological, creedal, or dogmatic notions, rather than visual and material culture.

Although it must be mentioned that material culture seems chaotic at first glance, works of art related to UFO culture — with any aesthetic level and under any judgment — could be listed at length. These representations have various effects: some works make people laugh, others entertain, still, other pieces might inspire individuals to reflect on current economic, environmental, or cultural crises.

In addition, many methodological questions might emerge concerning the comparative analysis of such diverse phenomena. For example, after having exhausted the energy sources of their alien world, the extraterrestrials in movies often attack our planet to subjugate the human race. In contrast, participants in UFO parades wearing alien masks and costumes may envision the aliens as messiahs who will arrive and save our planet from self-destruction. Alternatively, there is still the vexing question for scholars of how to compare diverse beliefs in aliens with the crop circle phenomenon in many parts of the world. Furthermore, as the number of such artifacts increases, along the proliferation of new beliefs, so does the confusion about meanings. UFO culture is a complex phenomenon that cannot be analyzed from a single perspective. They have far-reaching — but not coherent-worldviews with diverse manifestations, functions, and structures historically and in varied cultural contexts. What David Morgan highlights concerning religious material culture is valid in this case too: " $[\mathrm{t}]_{\mathrm{o}}$ universalize any of them as characteristic of religions anywhere and at any time is what anthropologists and philosophers and scholars of religion have prudently warned against" (Morgan, 2010b: 2). The mere description of an image, a symbol, or music lacks all the meaning-making aspects that help us understand the significance and role in the individual's life and vernacular worldview. Answers to ontological questions such as how, why, and when these objects appeared comes from placing them into their cultural context. But it also makes sense to understand and reveal the given society, the spirit of the age with its visible and invisible worlds, worldview, desires, and fears. In addition to regional diversity, UFO culture exist in different forms with different characteristics in the 1950s than today. In order to reveal their meaning, none of the UFO culture-related artifacts can 
be investigated separately in isolation but only in regard to their cultural background and discourse analysis. For instance, in the case of UFO abduction experiences, the drawings of alien astronauts and their spaceships by believers are as equally important as the abduction narratives, as meaningful and inseparable components of the overall experience, and must be taken seriously by scholars.

Moreover, the researcher's attitude, motivation, and aim also might have severe distortive effects in interpreting UFO cultural artifacts. Such objects and art have different meanings for believers who interpret them as reflections of reality than for skeptics who see them as absurd imagination and fantasy (Rothstein, 1996: 270). Naturally, we can encounter the same distinction in the approach and study of religion in general. Similarly, as a significant proportion of works of art are religiously bound, serve religious purposes, and convey a religious message in symbolic language (Belting, 2011), a significant segment of works related to UFO culture have religious connotations. For instance, a miraculous statue at a Catholic pilgrimage place is "reality", considered a hierophany with immanent transcendence for believers; the same object may be viewed as idolatry or blasphemy for the followers of a different religion who might even feel that it is their "sacred duty" to destroy the object.

Obviously, researchers also have different interpretations of the given artifact or object that those of believers and skeptics. The outward representations of aliens, for instance, are far more than pure external marks for them. The humanoids from Venus appearing at George Adamski's abduction narratives, for example, clearly indicate the links between UFO culture and Theosophy, as earlier Theosophists, like Helena Blavatsky (the founder of Theosophy) associated life on other planets with "Venusian masters" (Rothstein, 1996: 274-275.) While the evil, beetle-eyed aliens with tentacles that dominated the comics of the 1930s, and the more humane and semi-angelic ET astronauts in the accounts of the 1950s, who are concerned about the fate of humanity, clearly illustrate the distinct fears of the interwar era and the atomic age. As Wojcik observes, s "[u]nlike the pre-Second World War conceptions of bug-eyed monsters from outer space depicted in pulp fiction, the aliens encountered at the dawn of the atomic age are human-like in appearance and are depicted as rational, benevolent and beautiful beings with superhuman abilities" (Wojcik, 2003: 276).

\section{THE PHENOMENOLOGICAL APPROACH}

Scholars of religious art regularly note that the study of religions does not devote much space to the "aesthetic expression" of the transcendent, and none of the classical scholars (e.g., Durkheim, Mauss, Otto) have addressed "the poetic willingness of the human soul, and its ability to represent the saint and to express beauty" (Delahoutre, 2003: 125). Albeit, as Delahoutre notes, "the saint cannot be separated from the artistic conduct manifested in deeds and speech. There are no myths without poets; there are no rituals without priests celebrating them with splendor; there are no feasts without songs, dances, face painting, 
masks, totemic depictions, decorations, and special costumes [...] without homo poeticus or homo aestheticus, there is no homo religiosus" (ibid.: 126). This is especially true for the analysis of new religious and religious renewal movements, as well as vernacular religion. Only few pioneers have scrutinized the material culture of alternative and new religious expression / movements, whereas researchers studying religion might easily find a real treasure chest of unexplored expressive culture and data. ${ }^{4}$

\section{GROUPING BASED ON AESTHETIC VALUES}

When analyzing the material and artistic dimension of UFO culture, even categorizing the artifacts might cause serious problems right away. From an aesthetic point of view, we come across 1) works of art, which are often difficult to separate from 2) popular art appearing on mass-produced items and in online space and magazines, 3) symbols of UFO religions; while 4) everyday, ordinary objects with little or no aesthetic value could be found mostly on mugs, t-shirts, or kitsch.

However, aesthetic experiences vary from individual to individual, and therefore, rather than approaching from the outward "artistic" or aesthetic aspect, it is more appropriate to investigate the function of objects. From the functionalist perspective, there is no judgment about whether a tattoo representing an alien or a t-shirt with a flying saucer image is art or not, what matters is the meaning and function of the object for the individual and/or community.

\section{... AND ACCORDING TO GENRES}

Classifying the object based on its genre is another way to approach UFO cultural items but does not lead to significantly more insights than the aesthetic approach. The listing of the genres of UFO culture results in nothing more than an outward description of forms. With such an approach, it is relatively easy to find that paintings, music, fashion (clothing, posters), films, literature are popular forms, while architecture and sculpture are not, which is perhaps the same for other new religious movements. For apparent reasons, music - an inseparable element of rituals - together with symbols representing group identity, and mass-producible images on clothes and flags - are the first artistic objects to appear in the material culture of new religious movements. However, such movements usually begin with little financial resources for the creation of art. In most cases, it is only after a long time and a significant money infusion can such movements afford to buy private property and pay artists to decorate the environment with ornaments, paintings, and sculptures designed according to their tastes, and stylistic and semiotic preferences. Therefore, this

4 See Orsi, 1985; Flores-Pena, Evanchuk, 1994; Primiano, 1995; Polk, 1997; Magliocco, 2001; Sciorra 2015; Introvigne, 2016; Wojcik, 2016. 
approach to UFO art is not an exclusive feature of UFO culture, and more information could be obtained investigating how these objects are used and what role they fulfill in everyday culture.

\section{THE FUNCTIONALIST APPROACH}

From the functionalist perspective 1) works of art make up perhaps the smallest segment of the material dimension of UFO culture. Due to their decorative value, the primary function of such objects usually is spectacle and aesthetic pleasure. However, this category also includes particular earlier works of art that UFO enthusiasts believe to reveal the signs of extraterrestrial spaceships in the past. These remythologizing ideas often are connected to paleoastronautics, a theory which states that the evolution or genesis of human civilization occurred due to alien visitations on the Earth, and extraterrestrial intelligent beings have intervened in the development of human culture (Pauwels, Bergier, 1960). Therefore, paleoastronautics is predisposed to reinterpret the ufological symbolic meaning of earlier myths, religious scripts, and works of art originally unrelated to UFO culture. That is why the rock art in Bohuslän (Sweden), the ruins in Baalbek (Lebanon), or the pyramids in Egypt have appeared as proofs of earlier human-alien contacts in the influential works of Pauwels and Bergier, or von Däniken in the 1960s and 1970s. For those who believe in such theories, these are no longer merely monuments, or works of art and human achievement, but also signs: they show that extraterrestrial spacecraft have been not only observed in the present time but much earlier, and these become the fundament of "ancient astronaut" theory as well. The emergence of this theory could not happen before the postmodern age. Its essential precondition was the spread of deconstructionism, which questions the monolithic interpretations of cultural products, the reconstruction of the meaning-making process, and textual criticism.

2) Within UFO culture, there are significantly more "evidence objects" with more semantic functions and less aesthetic valuation. These are, for instance, photographs published in the press of allegedly crashed UFOs or objects retrieved from an alien spaceship. In this consideration, crop circles are signs too, which became a media sensation on an almost daily basis in the 1980s. Crop circles are believed by many to be traces of extraterrestrial spacecraft where outstanding radiation could be measured, while others think circles were somehow created by scientifically undetectable Earth energy fields, or by human time travelers from the distant future to help their navigation, or by aliens either physically or by using invisible energy beams from space. From an aesthetic point of view, "circles" became more and more complicated and elaborated over time, often not even in the form of a circle but as geometric figures (Meder, 2007). In addition to these, the flying saucer itself might also be an iconographically interpretable symbol. Jung proposed that the social fears of the Cold War era were behind the UFO phenomenon as well as primal instincts (e.g., sexuality, a sense of insecurity) that he derived primarily from the shape of the alleged alien spaceships: 


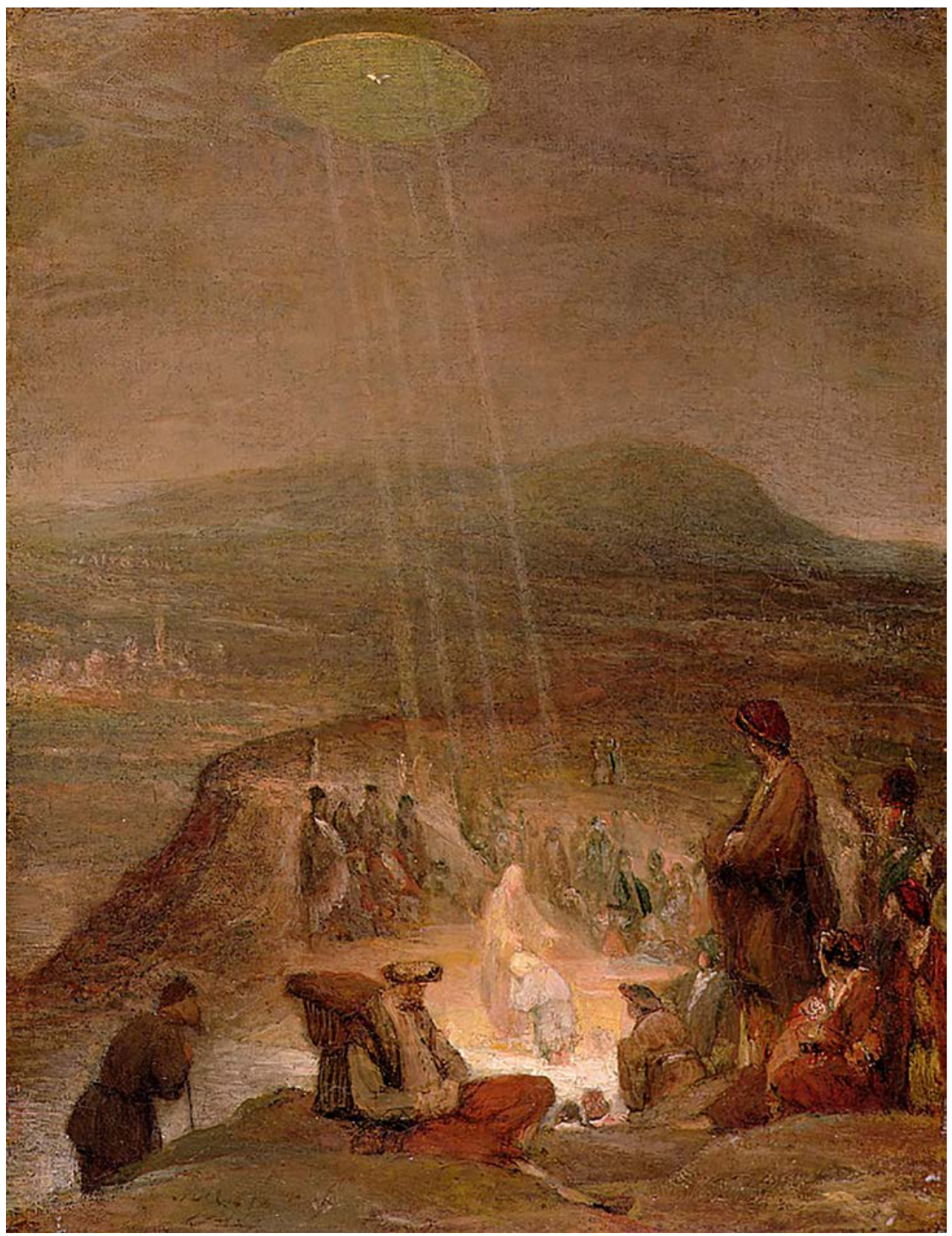

Figure 2. A UFO above John the Baptist? Aert De Gelder: The Baptism of Christ (c. 1710), Fitzwilliam Museum, Cambridge. 


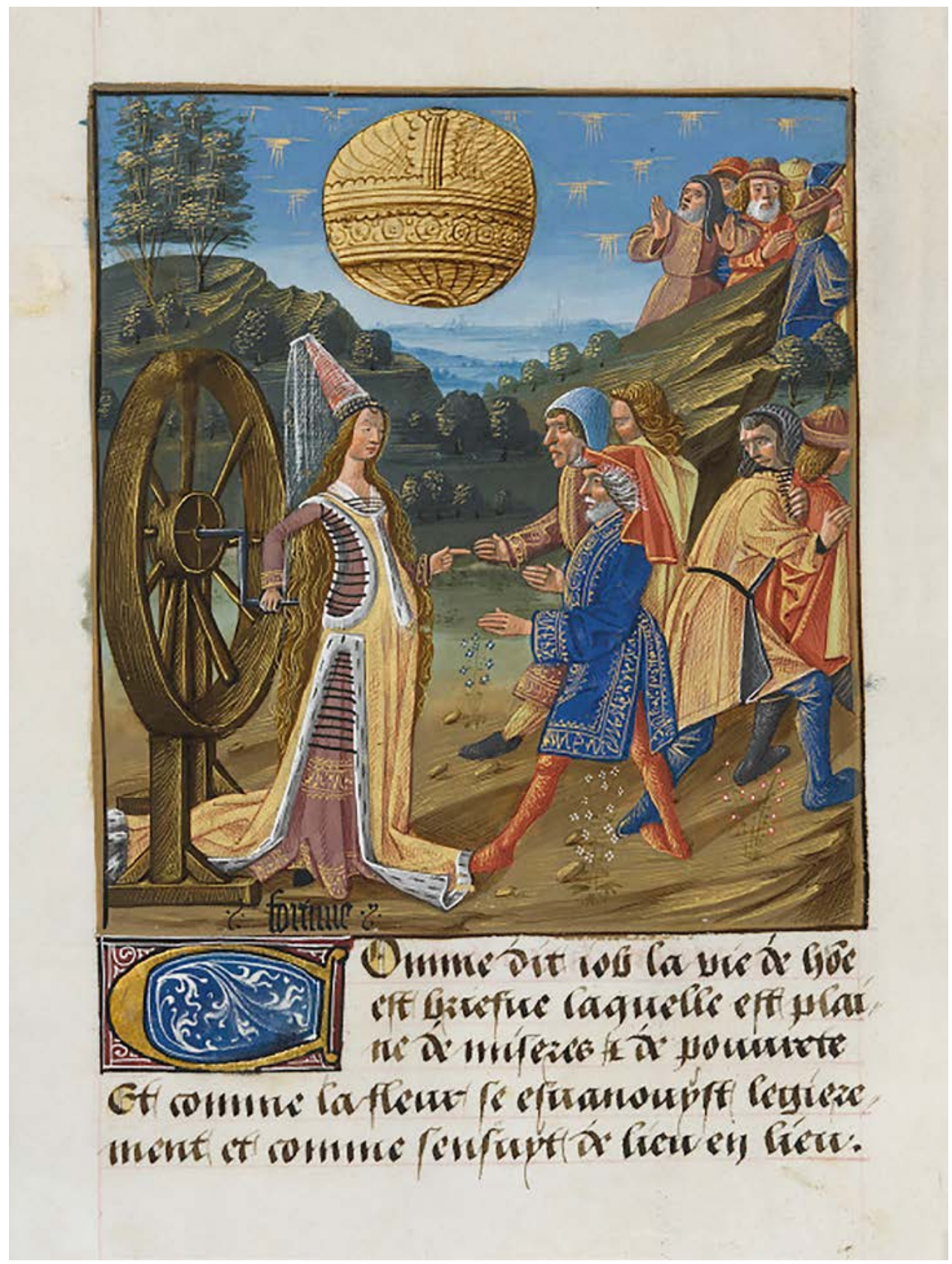

Figure 3. A UFO from 1338? Jacques Legrand: Le livre des bonnes moeurs (https://art.rmngp.fr/fr/ library/artworks/le-livre-de-bonnes-moeurs-de-jacques-legrand_peinture-sur-papier_parchemin5d2ef49a-e744-4e2e-96fa-9b89ffb74d6c). 


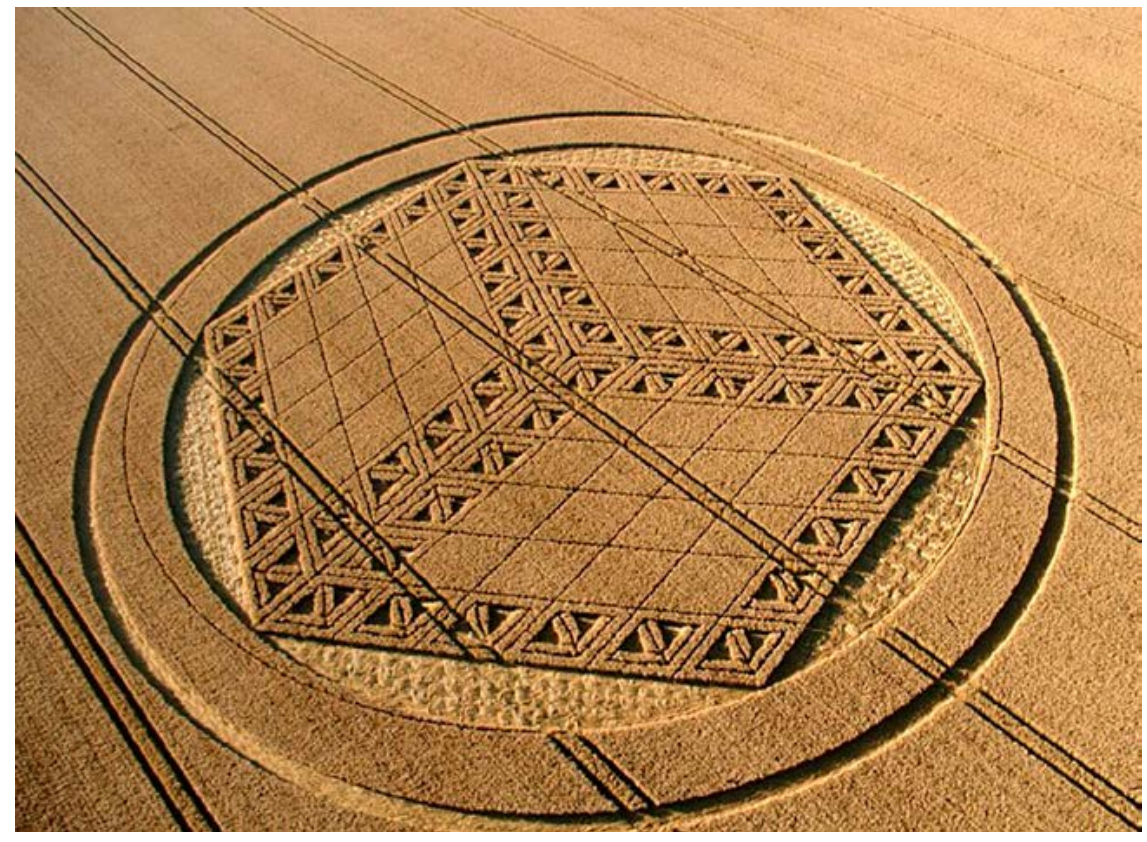

Figure 4. A crop "circle" of a more geometric type (http://www.erdekesvilag.hu/gabonakorok-a-vilag-minden-tajarol/).

For these reasons the sexual aspect of the Ufos merits our attention, as it shows that a very powerful instinct like sexuality has its share in the structure of the phenomenon. It is probably no accident that in one of the dreams we have been discussing a feminine symbol appears, and in the other a masculine, in accordance with the reports of lens-shaped and cigar-shaped Ufos, for where one appears, we may also expect its partner [...]. The psychological experience that is associated with the Ufo consists in the vision of the rotundum, the symbol of wholeness and the archetype that expresses itself in mandala form. Mandalas, as we know, usually appear in situations of psychic confusion and perplexity [...]. and the weltering confusion is held together by the protective circle. (Jung, 1978 [1959]: 44, 117)

However, works of art, such as those depicting personal UFO experiences, can also function as "evidence objects". A pioneering analysis on outsider art was made by Daniel Wojcik, who not only introduced the visionary paintings of Ionel Talpazan (1955-2015) about his encounter of a blue light from a flying saucer in the 1960s, but in addition to the general UFO mythology, he added Talpazan's memories ${ }^{5}$ and experiences of trauma to the analytical frame (Wojcik, 2016: 216-225, 2022).

5 Talpazan escaped from communist Romania to Yugoslavia by swimming across river Danube and then was granted refugee status and relocated to New York City (Wojcik, 2016: 220-221). 


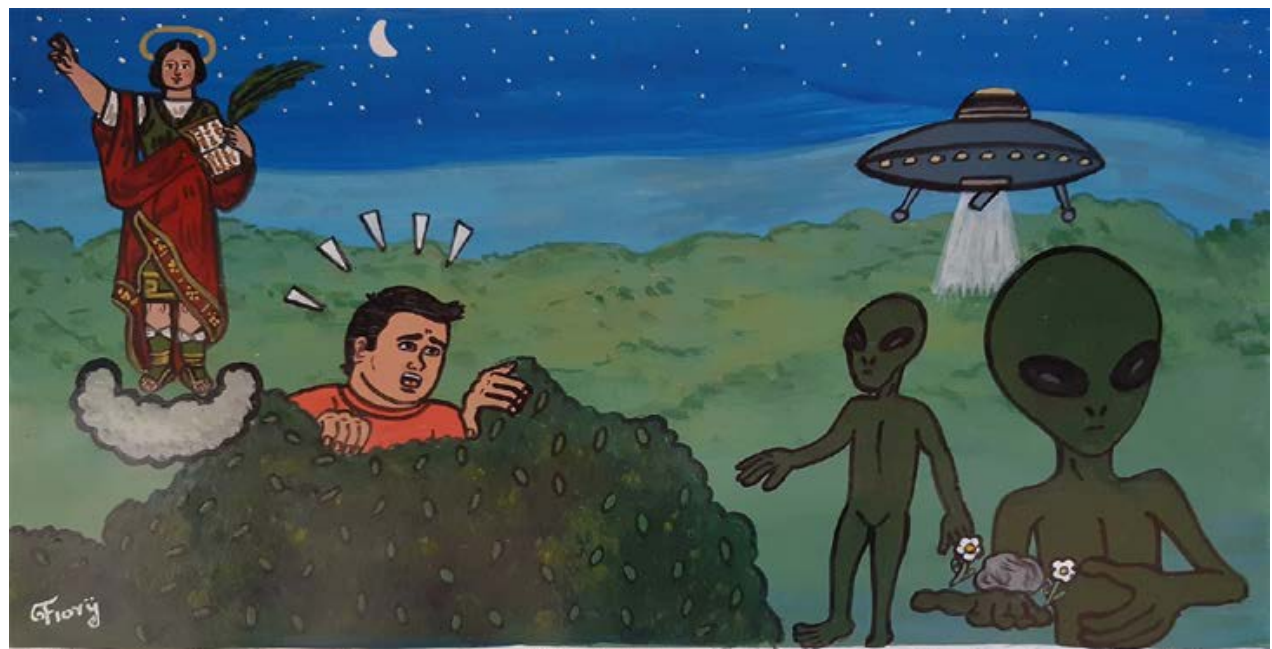

I ba por la carretera en mi bicicleta pues me gusta hacer ejercicio por las noches cuando de repente vi una luz muy extraña en el cielo y por curioso la segui y enorme fué mi sorpre sa al descubrir que era una nave espacial. Le doy las gracias a San Pancracio con mucha fé de que pude esconderme detrás de unos arbustos y asi no me vieron los marcianos que andaban por ahí. Poderico R., Tlaxcala México-

Figure 5. Encountering with Aliens. From the collection of István Povedák (photo by István Povedák, 2021).

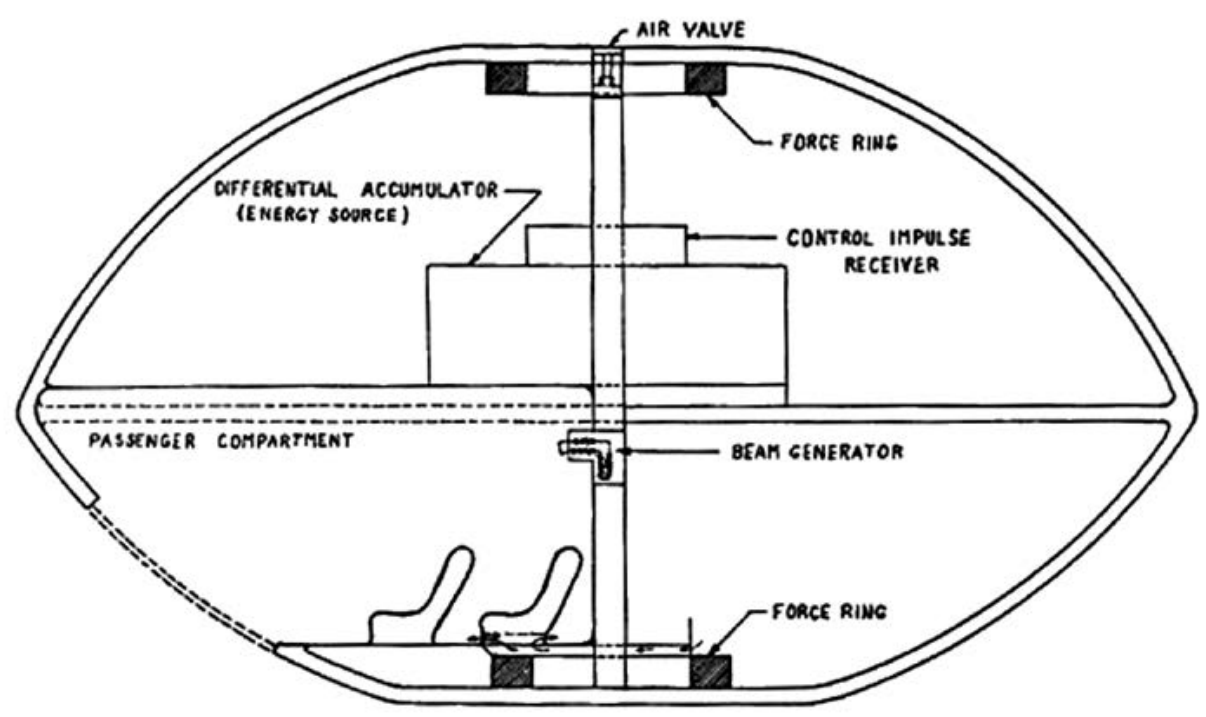

Figure 6. Fry's drawing of the UFO he allegedly traveled with on July 4th, 1950 (https://danielfry. com/daniels-writings/white-sands-incident/). 
This category also includes non-artistic works and drawings that depict the extraterrestrial world or a personal experience of alien abduction. In addition to the figures, some of these-like the depictions of medieval chronicles - contain narratives and depict the entire timeline of the story. (See the retablo shown in Figure 5.) Such works reveal human imagination, an elusive dimension of human experience, recognize the nuances of felt life, discern its importance for people, and display things that words cannot translate. Nevertheless, it should also be kept in mind that not every work may have a deeper meaning, and not "everything must mean something", and sometimes these artifacts belong to the mere aesthetic dimension of human behavior (Morgan, 2010a: xiii).

3) It is not easy to demarcate the boundaries of works of art with entertaining functions. A separate volume could be devoted alone to introduce the alien-myth and its changes in movies from the past more than a hundred years. It would be a grandiose enterprise to analyze the sci-fi movies that have become popular since the Lumiére brothers' "A Trip to the Moon" (1902). However, two things are worth noting. On the one hand, there is an obvious connection between such films and the popularity of UFO culture. In addition to drawing from UFO beliefs, the movies also play an influential role due to their popularity and they may amplify the already existing concepts concerning UFOs. Meanwhile, they also serve as a source of ideas for the dissemination of such beliefs. It is unclear to what extent there is an increase in the number of UFO sightings after sci-fi movies (there is no data on this, see Clark, 1996: 90-91), but no doubt UFO movies and UFO encounter narratives thematically intertwine and mutually reinforce each other. Emphasizing his skepticism in this regard as early as the 1960s, Hermann put it this way: "UFO literature has also taken over a lot from utopian films, and sometimes there is a faint suspicion in me that the whole UFO turmoil was staged solely to promote such films [...] "The Flying Saucer movie» called "The Day the Earth Stood Still« is said by some to be inspired by extraterrestrial beings. The production managers of 20th Century Fox must have been pleased about that" (Hermann, 1966: 145).

At the same time, there is an interesting paradox between the extraterrestrial images in popular sci-fi movies and the images that appear in UFO encounter narratives. The majority of films and TV series depict malevolent and dreadful aliens (e.g., War of the Worlds, the Alien series, Mars Attacks, Signs, The Edge of Tomorrow, Independence Day), while only a few contain innocent and benevolent aliens (e.g., Close Encounters of the Third Kind, E.T). While most of the extraterrestrial creatures in the filmic depictions arrive on Earth with conquering, invasive, and harmful intentions, the vast majority of real-world UFO experience narratives express just the opposite. Although in some of the abduction narratives the aliens are invasive and amoral, treating humans like animals to breed with, and conspiracy theories on reptilians also claim the shoplifting aliens arrived with the aim to control human society, still, the majority of abduction narratives report the alien's concern about the future of our world and humanity. In encounter narratives, the myth of the mostly benevolent aliens portrays humanity in the same guise as movies characterize 
the extraterrestrial invaders. Myth and anti-myth with bipolar opposition in their worldview are confronting each other. In Roland Barthes' words, the movies reflect a "pettybourgeois myth" that is incapable of acknowledging and accepting the Other and instead must anthropomorphize the extraterrestrials. They are endowed with human intentions (conquest, exploitation, ensuring their survival, etc.) through which they become disliked, fearful, unpredictable, anti-heroic. Using Barthes' idea,

“otherness is the most repulsive concept possible for 'common sense'. Every myth is fatally attracted to some narrow anthropomorphism [...] Mars is not simply the Earth, but the petty-bourgeois Earth, the petty mindset nurtured and expressed by high-volume postcards. Barely formed in the sky, Mars is already engulfed in expropriation: the sameness." (Barthes, 1983: 56)

However, anthropomorphism is not just a projection of negative human qualities. Non-human space sagas like Star Trek, Star Wars, or some Marvel movies also contain sentient or humorous strangers. In addition, the films in this realm are not only imaginative, but sometimes silly stories (e.g., Paul, $A l f$ ) with entertaining functions. But they often also reflect the fears, conflicts, and crises of contemporary society. Such films create an opportunity to talk about the anxieties of the moment, from climate change to international migration or the constant search for the meaning of life. Among the various topics of alien movie sub-genres, there are some express human xenophobia (Avatar, District 9), the fear of terror (Cloverfield, Independence Day), or people's distrust in politicians and the influx of conspiracy theories (X-files, Men in Black).

The works of art with entertaining functions include music too. Music is essential for this analysis as it has always reacted promptly and expressively to changes in contemporary culture. The songs and musicians that belong to this group could be divided into three groups: 1) musicians-be they either UFO believers or not-whose lyrics mention aliens in some sense; 2) manifesto-type songs that function as creeds, therefore represent a UFOmyth; and 3) the music of UFO-religions and organizations.

The first category might include UFO-believer performers whose songs are not necessarily tied to UFO culture, but their media representations reflect their faith. A number of rock'n'rollers testified that they saw a flying saucer-supposedly Elvis Presley, Jimmy Hendrix, Keith Richards, John Lennon, Lemmy-but not many celebrities became such an enthusiast and committed amateur UFO researchers as Robbie Williams, the former singer of Take That, or. Reg Presley (1941-2013) from The Troggs - the composer and performer of the hit songs "Wild Thing", "With a girl like you" or "Love is all around"who promoted and supported research on alien spaceships, alchemy and crop circles.

One of the earliest songs that mention flying saucers and their passengers is Ella Fitzgerald's “Two Little Men in a Flying Saucer” released early as 1951. As its title makes clear, Fitzgerald's funny song carried the hallmarks of UFO culture of the 1950s, which 
is primarily about accounts of experiences on flying saucers and the emergence of UFObeliever movements forming around such self-made "prophet-like" individuals. (See the essays in Partridge, 2003)

Manifesto-type songs whose performers practically recite their belief in the existence of extraterrestrial civilizations and their visitations on Earth may be placed in the next category. An early classic of the musical dimension of the UFO culture is Mollie Thompson's "From Worlds Afar" released in 1966, which summarizes a UFO believer's worldview with some humor. ${ }^{6}$ But even more well-known performers were inspired by the alien myth as it was tied to the psychedelic culture of the 1960s and 70s. "Mr. Spaceman" by The Byrds from 1966 was the first known piece of space rock. "It Came Out of the Sky" (1969) by Creedence Clearwater Revival tells the fictional story of an alien encounter filled with conspiracy theories from the year of the moon landing. The relatively wellknown British psychedelic space rock band Eat Static plays mainly instrumental electric music, although the titles of their albums clearly show the members' position concerning UFOs: Prepare Your Spirit (Alien Records, 1992), Abduction (Planet Dog Records, 1993), Implant (Planet Dog Records, 1995), Science of the Gods (Planet Dog Records, 1997), or the titles of Back to Earth (Interchill Records, 2008) and Dead Planet / Human Upgrade (Mesmobeat, 2015); these albums clearly resonate with the books by Erich von Däniken, as their covers and lyrics carry similar messages. The lyrics of the song "The first revelation" contain, for instance, paleoastronautic myths: "Crystal skulls were brought here by people from the sky, that were called sky-gods or sky-people. Everything that is communication comes from quartz crystal." A better known song is "Hangar 18" (1992) by one of the most popular trash metal bands, Megadeth, which explores the myth of an alien spaceship that is supposedly hidden at Wright-Patterson Air Base in Ohio: "Foreign life forms, inventory, suspended state of cryogenics, selective amnesia's the story, believed, foretold, but who would suspect?"; and "Arizona" by Robbie Williams (2009) with many references to "Area 51 " and UFO-conspiracies.

Impressionistic, experimental, and emotion-based UFO music is rather a collection of instrumental, meditative musical and sound effects that try to "make audible" the arrival of aliens and their messages in a sonic way. These include, among others, King Woetie, Atrium Carceri, or Sabled Sun. Although these musical works have an entertaining function, their meditative, contemplative message about UFOs is more dominant.

6 The lyrics of The Cockeyed Ballad by Thompson include "Those Flying Saucers whisking through our skies / Must take some power to make them rise. / But government departments just hide their eyes, / And call them meteors! ... / I suppose you know why I'm telling you this, / So you won't shriek or shake your fist / When you discover Martians do exist! / They're real nice fellows. / I know, 'cause I met one a week ago! / His ship came down for an hour or so. / He talked to me, but then he had to go. / Real interested I was! Got brothers on Venus and Saturn, it seems / Fly their ships on magnetic beams. / They wear one piece suits-you can't see any seams; / But apart from that-they're just like us!" 
The third category of UFO music includes music related to institutionalized UFO religions. For example, Richard Lawrence and Kevin Kendle Rise's "Peace Meditations" album, affiliated with the Aetherius Society, contains songs from the Cosmic Masters that energize and bring inner peace. Some of the songs by Claude Vorilhon (Raël), the founder of the Raëlian religion is of the manifesto-type genre (e.g., Rael Maitreya: Elohim, A Ray of Light), while others are worship songs praising extraterrestrial aliens (e.g., Love, Think of the Artists), or are about life wisdom (e.g., Life is a Cinema, Vive la vie). Even more so, the Raëlians-who otherwise support sex-positive feminism—have entertaining or even erotic texts (e.g., Sexophone, Rose), while some songs mock the negative depictions of UFO believers (e.g., It's a Cult).

The material dimension of UFO culture also includes commercialized mass products, which are primarily made for entertainment purposes and are used for the most part in festivals. Alien and UFO masks, uniforms, and accessories are usually based on the iconic alien and UFO depictions of sci-fi movies. It is worth mentioning comics and cartoons related to UFO culture, which became popular in the United States as early as the 1930s. Consequently, these influenced later sci-fi movies, or even the encounter experiences from the 1950s. Rothstein draws attention to the cover of the June 1935 issue of Astounding Stories magazine, which depicts an abduction by aliens, nearly three decades prior to the appearance of narratives of this kind (Rothstein, 1996: 279-280). However, it has to be noted that such a similarity cannot yet justify an organic connection between the two, especially not from such a thirty-year time perspective.

4) The symbols and artistic works of UFO religions belong to the fourth group of artifacts, and include symbols, ritual costumes, or buildings. These represent the physical manifestation of the theology of the UFO religions and their connections to other religious/ philosophical traditions. For instance, the symbol of the cross, the AUM sign, and the triangle used by the Aetherius Society show religious syncretism and the reinterpretation of symbols. Here the cross symbolizes the last teachings of Jesus, the "12 Blessings" that George King, the founder of the Aetherius Society, received. As King described it, the cross does not represent the sufferings, crucifixion, and resurrection of Jesus but contains all of His thoughts and energies that could influence its bearer. Therefore, the cross blessed by King could be possessed only by the chosen members of the group. Furthermore, when the cross was used in sacred places, the exhausted body of a believer could be fulfilled with its resonance (Gallagher, 2014: 224-226). Besides, the AUM for Aetherians symbolizes God, while the triangle symbolizes wisdom (Rothstein, 1996: 281-283). The Raëlians, who otherwise do not accept the existence of God, use the Star of David and the Swastika which, according to their (re)interpretation, represent the infinity of space and time. ${ }^{7}$ The Star of David, in their teachings, refers to the extraterrestrials with highly advanced technology who created life on Earth but will return and land in Israel with their spaceship.

http://rael.org/faq. 


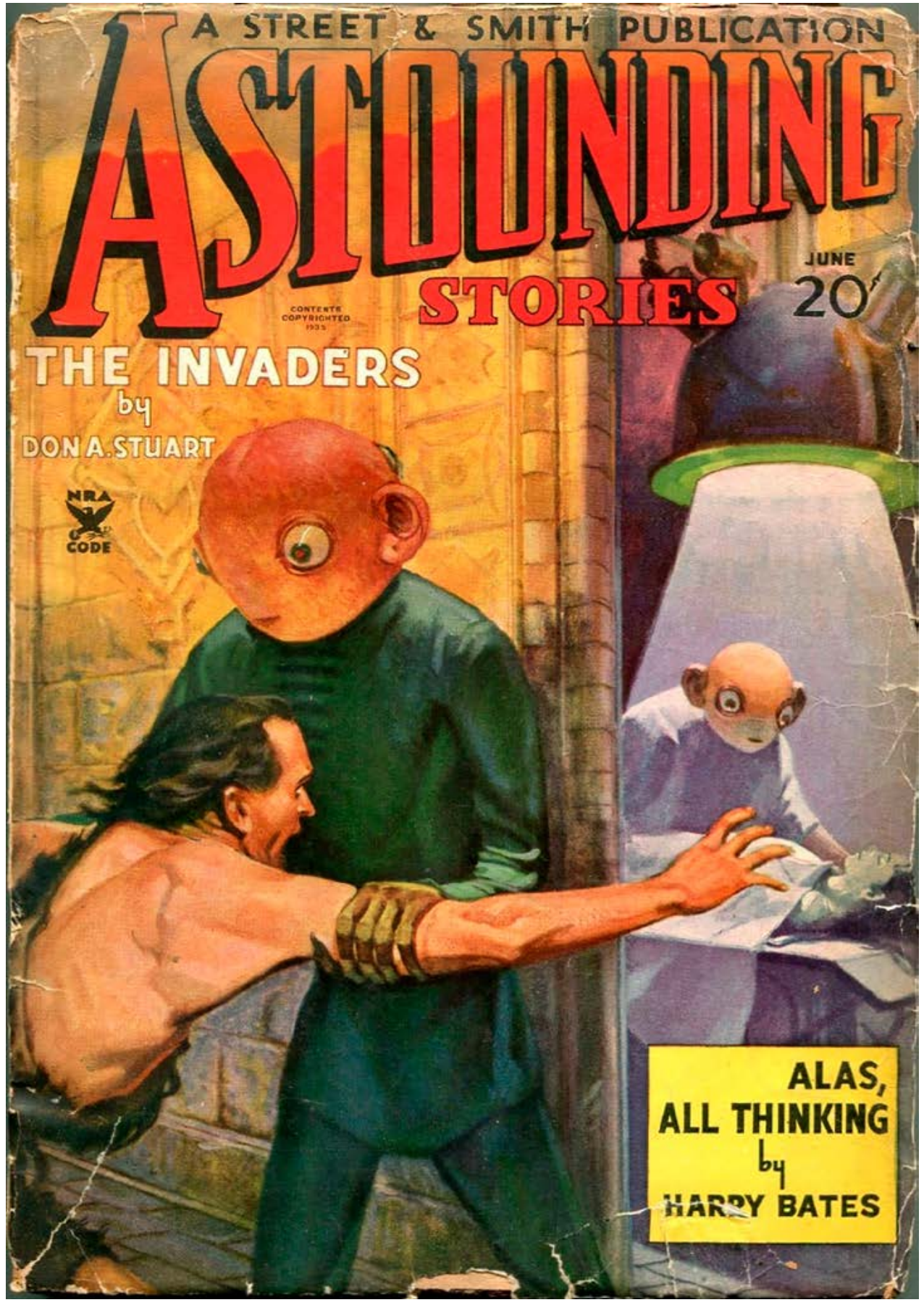

Figure 7. UFO abduction on the cover of Astounding Stories (June 1935) (http://lh5.google.co.uk/ abramsv/R3GxQ0KUdBI/AAAAAAAABuE/xdPAioDREvE/s1600-h/ast_3506.jpg). 
Therefore, the goal of the Raëlians is to build an extraterrestrial embassy near Jerusalem, which would be the third holy church of the city where the supernatural (in this case, extraterrestrials) would be present. ${ }^{8}$

The works of art associated with UFO culture could be presented here endlessly; however, that is not the intention of the framework offered in this essay. For instance, neither proto-UFO literature nor contemporary sci-fi novels or comics have been mentioned, as their analysis would extend back for up to "The Description of a New World, Called The Blazing-World” sci-fi utopia by Margaret Cavendish from 1666.

5) The last group of works of UFO art to be considered from a functional perspective involve identity-forming materials. Whether we talk about a carnival mask depicting gray aliens or a t-shirt with the symbol of a UFO religion, they all represent the worldview of those wearing them. These artistic, or semi-artistic creations and materials, therefore, have an identity-forming role, "emerging from and enfolded within the practices, things, and feelings that shape individuals and communities over time" (Morgan, 2010a: XIV).

\section{CONCLUSION}

In analyzing the material and artistic dimension of UFO culture, we can conclude that the double designation is justified. We are not merely talking about art, but a broader material dimension, within which creations made for artistic and non-artistic purposes might be distinguished. Classifying an object into the former or the latter category is relative, depending on many circumstances: it might be judged differently by the members of a UFO religion, the researcher, and the skeptic. Furthermore, as Maquet notes, it is unclear what could be considered art in some societies (or, in our case, in subcultures) (Maquet, 2003: 17). A work of art for an outsider observer might be embedded in the everyday reality of the group members so profoundly that they do not even consider that as art. The function of such object often is not artistic at all, but are symbols depicting what group members believe in and share as their worldview.

As it is also well-known, art is a meaningful segment of socially constructed reality; thus, just as plural societies exist, so do "many different realities" (Maquet, 2003: 21) constructed by various subcultures. As some forms of artistic expressions can also be interpreted as symbols, in addition to aesthetics, they function as group symbols too. On the other hand, the group-bounded nature of symbols means that different groups decode them differently. Therefore, their underlying "private" and "group" mythology is multilayered (Kapitány, Kapitány, 2005: 12), and superimposed by the characteristics of the given cultural and political circumstances of that age. Besides, it is not enough to emphasize the diversity and plurality of UFO culture and art and the multiplicity of interpretation,

8 http://elohimembassy.org. 
but the heterogeneity of UFO believers must also be highlighted. Considering believers and enthusiasts as a homogeneous group and assuming they blindly believe everything or that the depth and layers of their faith are the same would represent an essential mistake and misunderstanding, similar to that made of early anthropologists in their depictions of non-Western cultures. In the case of UFO culture, some individuals absolutely believe in the non-existing truth-value of the most obviously "fake" images, while others ignore the wild speculations of the rampant UFO culture, while the most moderate believers argue with or laugh at the former "true believers". And the same can be said about their relationship to the artistic or material dimension as each individual integrates these artistic and semi-artistic materials to various degrees into their everyday culture. To gain more information on the role of these artifacts in the vernacular religion and everyday lives of the individuals — whether they are UFO believers or "seekers"-requires an ethnographic approach, not possible here due to the limits of the length of this present study.

Finally, a question inevitably emerges in the study of this subject matter: why is there so much doubt and uncanny around UFO culture? Myths, whether UFO-related or otherwise, arise where knowledge is incomplete. If we had a complete and comprehensive understanding of the world and comforting information about all things and human existence, the essential condition of myth-making would be unnecessary or lost. Interestingly, images of UFO culture challenge notions of a safe and unshakeable knowledge of the world. The imagery of UFOs are seldom sharp or clear, and the details are usually difficult to recognize, as they are often blurry, photocopied several times, and imbued with mystery, mysticism, and uncertainty. Their multiple_-ambiguous and often controversial—interpretations are therefore inherent and unavoidable. From this perspective, they resemble the mysterious and obscure photos taken in Spiritualist séances that attempted to prove the existence of ghosts. As researchers of religious culture, we could say with some humor or with some real insight that this was to be expected, since the transcendent cannot be wholly understood, and most importantly, cannot be depicted (Otto, 1997 [1923]). Only their "imprint" in our world can be experienced. Although there are narratives about tall blonde extraterrestrials, reptilians, and small gray aliens, the images in the "debunking" magazines introduce only the latter type. And these are also blurry, out of focus, and pixelated as if these extraterrestrials would be unrepresentable, useable, and unknowable. These uncanny features of UFO materials and "alien images" show striking resemblance with what Otto described as numinous, an inexpressible, non-rational, non-sensory experience of the transcendent in the mundane world. Similar to his hundred-year-old statements on the idea of the Holy, extraterrestrials in contemporary UFO culture are mysterium tremendum et fascinans. Mysterious that are terrifying and fascinating at once. 


\section{REFERENCES}

Barkun, Michael. 2003. A Culture of Conspiracy. Apocalyptic Visions in Contemporary America. Berkeley, Los Angeles: University of California Press. DOI: https://doi.org/10.1525/california/9780520238053.001.0001.

Barthes, Roland. 1983 (1956). Mitológiák. Budapest, Európa.

Belting, Hans. 2011. An Anthropology of Images: Picture, Medium, Body. Princeton: Princeton University Press.

Bullard, Thomas E. 2010. The Myth and Mystery of UFOs. Lawrence: University Press of Kansas.

Cielebiaś, Piotr. 2015. UFOs over Poland: The Land of High Strangeness. West Yorkshire: Flying Disk Press.

Clark, Jerome. 1996. High Strangeness: UFOs from 1960 through 1979. The UFO Encyclopedia: Vol. 3. Detroit: Omnigraphics Inc.

Colavito, Jason. 2011. The Origins of the Space Gods: Ancient Astronauts and the Cthulhu Mythos in Fiction and Fact. https://www.jasoncolavito.com/origin-of-the-space-gods.html.

Delahoutre, Michel. 2003. A szent és esztétikai kifejeződése: szent tér, szent művészet, vallási műemlékek. In A szent antropológiája: A homo religiosus eredete és problémája, ed. Julien Ries, 125-148, Budapest: Typotex.

Farcas, Dan D. 2016. UFOs over Romania. Pontefract: Flying Disk Press.

Flores-Peña, Ysamur, and Roberta J. Evanchuk. 1994. Santeria Garments and Altars: Speaking Without a Voice. Jackson: University Press of Mississippi.

Gallagher, Eugene V. 2014. Reading and Writing Scripture in New Religious Movements: New Bibles and New Revelations. New York: Palgrave MacMillan.

Hermann, Joachim. 1966. Hamis világképek: Csillagászat és babona. Budapest: Gondolat.

Introvigne, Massimo. 2016. New Religious Movements and the Visual Arts. Nova Religio 19 (4):3-13. DOI: https://doi.org/10.1525/nr.2016.19.4.3.

Jacobs, David M. 1975. The UFO Controversy in America. Bloomington: Indiana University Press.

Jacobs, David M. 1992. Secret Life: Firsthand Documented Accounts of UFO Abductions. New York: Fireside Books.

Jung, Carl Gustav. 1978 (1959). Flying Saucers: A Modern Myth of Things Seen in the Skies. Princeton: Princeton University Press.

Kapaló, James A., and Kinga Povedák. 2022. Introduction: Reframing the Religious Underground. In The Secret Police and the Religious Underground in Communist and Post-Communist Eastern Europe, eds. James A. Kapaló and Kinga Povedák, 1-36. New York, Abingdon: Routledge.

Kapitány, Ágnes, and Gábor Kapitány. 2005. Tárgyak szimbolikája. Budapest: Új Mandátum.

Kapitány, Ágnes, and Gábor Kapitány. 2015. A modern mitológiák szemiotikájához. In Már a múlt sem a régi... Az új magyar mitológiák multidiszciplináris elemzése, eds. László Attila Hubbes and István Povedák, 40-61. Szeged: MTA-SZTE Vallási Kultúrakutató Csoport - MAKAT Modern Mitológiakutató Mühely.

Köiva, Mare. 1996. Some Aspects of Ufolore. In Contemporary Folklore: Changing World View and Tradition, ed. Mare Köiva, 254-266. Tartu: Institute of Estonian Language \& Estonian Museum of Literature.

Lewis, James R., ed. 2003. Encyclopedic Sourcebook of UFO Religions. Amherst: Prometheus Books.

Magliocco, Sabina. 2001. Neo-Pagan Sacred Art and Altars: Making Things Whole. Jackson: University Press of Mississippi. 
Maquet, Jacques. 2003. Az esztétikai tapasztalat: A vizuális müvészetek antropológus szemmel. Debrecen: Csokonai.

Meder, Theo. 2007. Crop Circle Tales: Narrative Testimonies from the Frontier Science Movement. In Reframing Dutch Culture: Between Otherness and Authenticity, eds. Peter Jan Margry and Herman Roodenburg, 135-157. Aldershot: Ashgate.

Morgan, David. 2010a. Preface. In Religion and Material Culture: The Matter of Belief, ed. David Morgan, xiii-xiv. London, New York: Routledge.

Morgan, David. 2010b. Introduction: The matter of belief. In Religion and Material Culture: The Matter of Belief, ed. David Morgan, 1-17, London, New York: Routledge.

Orsi, Robert A. 2010 (1985). The Madonna of 115th Street: Faith and Community in Italian Harlem, 18801950. New Haven, London: Yale University Press.

Otto, Rudolf. 1997 (1923). A szent [The Idea of the Holy]. Budapest: Osiris.

Partridge, Christopher, ed. 2003. UFO Religions. London, New York: Routledge.

Pauwels, Louis, and Jacques Bergier. 1989. Mágusok hajnala: Bevezetés a fantasztikus realizmusba. Budapest: Móra Könyvkiadó.

Polk, Patrick A. 1997. Hatian Vodou Flags. Jackson: University Press of Mississippi.

Presley, Reg. 2002. Wild Things They Don't Tell Us. London: Metro Books.

Povedák, István. 2018. Az UFO kultúra társadalomtudományi elemzése. In Tapasztalatból hallottam... Alternativ világképek, összeesküvés elméletek társadalomtudományi elemzése, eds. István Povedák and László Attila Hubbes, 138-194. Szeged: MTA-SZTE Vallási Kultúrakutató Csoport - MAKAT Modern Mitológiakutató Mủhely.

Povedák, István. 2019. The Future that Changed the Past: A Narrative-level Analysis of UFO Culture with Special Regard to Paleoastronautics behind the Iron Curtain. In Present and Past in the Study of Religion and Magic, eds. Éva Pócs and Ágnes Hesz, 363-389. Budapest: Balassi Kiado.

Povedák, Kinga. 2011. Did you Bring New Songs?: The Role of Contemporary Catholic Music in Hungary. Acta Ethnographica Hungarica 56 (1): 31-41. DOI: https://doi.org/10.1556/AEthn.56.2011.1.4.

Povedák, Kinga. 2014. Catholicism in Transition: The 'Religious Beat' Movement in Hungary. In Christianity in the Modern World - Changes and Controversies, eds. Giselle Vincett and Elijah Obinna, 139-156. Farnham: Ashgate.

Primiano, Leonard Norman. 1995. Vernacular Religion and the Search for Method in Religious Folklife. Western Folklore 54 (1): 37-56. DOI: https://doi.org/10.2307/1499910.

Ramet, Sabrina P. 2003. UFOs over Russia and Eastern Europe. In KAZAAAM! SPLAT! PLOOF!: The American Impact on European Popular Culture since 1945, eds. Sabrina P. Ramet and Gordana P. Crnković, 198-218, Lanham: Rowman \& Littlefield.

Rothstein, Mikael. 1996. Images for the Mind and Images for the Eye: An Iconographical Approach tö UFO-Mythology. In Dance, Music, Art, and Religion, ed. Tore Ahlbäck, 269-294. Åbo: The Donner Institute for Research in Religious and Cultural History.

Rothstein, Mikael. 2009. World Saviour in Undergarnments: The Palpable Jesus of the Aetherius Society. In Alternative Christs, ed. Olav Hammer, 256-274. New York: Cambridge University Press.

Sciorra, Joseph. 2015. Built with Faith: Italian American Imagination and Catholic Material Culture in New York City. Knoxville: The University of Tennessee Press.

Taylor, Charles. 2008. Modern, modernitás, modernizmus, modernizáció. In Sokféle modernitás: A modernizáció stratégiái és modelljei a globális világban. eds. Péter Niedermüller et al., 19-33. Budapest: L’Harmattan. 
Wojcik, Daniel. 2003. Apocalyptic and Millenarian Aspects of American UFOism. In UFO Religions, ed. Christopher Partridge, 274-300. London: Routledge.

Wojcik, Daniel. 2016. Outsider Art: Visionary Worlds and Trauma. Jackson: University Press of Mississippi. Wojcik, Daniel. 2022. Artist as Astronaut: The Otherworldly Art of Ionel Talpazan. London, Cambridge: Strange Attractor, MIT Press.

\section{UMETNIŠKA IN MATERIALNA RAZSEŽNOST KULTURE NLP}

Čeprav je mitologija NLP (naznani leteči predmeti) sestavni del svetovne popularne kulture že od srede 20. stoletja, so njene razsežnosti in manifestacije še neenakomerno raziskane. Težižšce raziskovalcev je bilo skoraj izključno usmerjeno v mitološke, verske ali dogmatske predstave, medtem ko "materialni obrat" religioznih raziskav nanje skoraj ni vplival. Posledično je zaznavna, tj. vidna, otipljiva in slišna, razsežnost kulture NLP večinoma ostala terra incognita.

Avtor predstavlja umetniške in materialne razsežnosti kulture NLP, poudarja kompleksnost pojava ter potrebo po uporabi več perspektiv. Pogledi kulture NLP na svet so v vsakem zgodovinskem obdobju in v različnih kulturnih kontekstih neskladni z različnimi manifestacijami, funkcijami, strukturami in ocenami. Medtem ko je kultura NLP na t. i. zahodni polobli razmeroma dobro raziskana, o tem pojavu v postsocialističnih državah skoraj ni informacij. V nasprotju $z$ "zahodnim svetom", kjer je bila kultura NLP sestavni del popularne kulture, sta bila v nekdanjih komunističnih državah obstoj nezemeljskih civilizacij in njihova možna obiskovanja na Zemlji le redko predmet, opazen v javnem diskurzu.

Kultura NLP je imela v času bladne vojne drugačne značilnosti kakor danes. Nemogoče je govoriti o enotni skupnosti "vernikov NLP «, saj obstajajo pomembne razlike in celo antagonizmi o tem, kaj verjamejo, kako verjamejo in kakšno vlogo ima to v njihovi vernakularni kulturi.

Za predstavitev materialne in umetniške razsežnosti kulture NLP je avtor preučil različne artefakte (npr. slike, glasba, simboli, krogi na žitu, filmi) sfunkcionalističnega in fenomenološkega vidika, ne da bi pri tem presojal njihovo umetniško ali neumetniško raven. Cilj je osvetliti sivo liso v preučenosti kulture NLP in spodbuditi nadaljnje raziskave.

Dr. István Povedák, MOME, University of Art and Design Budapest, Institute for Theoretical Studies, povedak@g.mome.hu

This publication is an outcome of the ERC CZ project no. LL2006 (ReEnchEu) funded by the Czech Ministry of Education, Youth, and Sport and headed by Alessandro Testa at the Department of Sociological Studies, Faculty of Social Sciences, Charles University in Prague. 